\title{
Masses are Other People
}

\author{
Jefferson D. Pooley \\ Muhlenberg College \\ pooley@muhlenberg.edu \\ jeffpooley.com
}

Essay to appear in an invited forum of Journalism \& Mass

Communication Quarterly 


\section{Masses are Other People \\ Jefferson D. Pooley, Muhlenberg College, pooley@muhlenberg.edu}

\section{September 2021}

The obvious ReAson to drop the word "mass" from our disciplinary name is that social reality has moved on. "Mass communication" is irredeemably linked to the broadcast era and one-to-many dispersal. "We are back," as John Durham Peters (2015, p. 5) has observed, "to the age-old modes of some-to-some, one-to-few, and even one-to-none." Big, reception-ready audiences still gather, but the mediums that do lots of our mediating aren't shaped like funnels any more. So the "mass" of "mass communication" - as a catch-all for the field-is plainly outdated.

There is another reason to drop the label. The word "mass" comes freighted with a history of abusive associations. A "mass," as the term came to be used in the late nineteenth century, referred to a mob-to a crowd-in-waiting, suggestible and bovine. "Mass" was a pejorative linked to a warning: popular democracy is dangerous. Raymond Williams (1958) drew out the term's fundamentally ascriptive character: "There are in fact no masses; there are only ways of seeing people as masses" (p. 319). Masses, he added, "are other people" (p. 319).

The story of the word and its worldview is well-documented. In the 45 years since Robert Nye's (1975) The Origins of Crowd Psychology, a large literature has tracked the fear-drenched discourse triggered by popular literacy, an expanded franchise, and labor unrest in the late 180os (see Borch, 2012, pp. 10-15). Gustav Le Bon (1896), an influential European voice among many others, raised the alarm: "To-day the claims of the masses are becoming more and more sharply defined, and amount to nothing less than a determination to destroy utterly society as it now exists" (p. xvii). The specter of "the masses" was taken up with real vigor in the United States, by the emerging disciplines of political science and sociology (Frezza, 2007).

By the late interwar years, it's true, some of the term's pejorative stain had been rubbed off. Scholars like Chicago's Herbert Blumer (1939) proposed a more antiseptic, if still charged, definition of mass, as a collection of spread-out, isolated individuals cut off from "customary moorings" and left to cope with a "new and wider world" (p. 244). In the aftermath of World War II, when the "mass communication" phrase won its footing, "mass" was frequently used to modify "society." On this view, mass society refers to an inert, atomized, faceless multitude stretched continent-wide; to many, including 
some traumatized European emigrés, mass society looked like fertile, it-could-happen-here soil for fascism.

We labor under the illusion that "mass" is a descriptive. But it is also, to borrow Williams' language, a prejudice. Decades of socialscientific laundering have not washed out the word's class-stained residue. The point, crucially, applies to the full "mass communication" phrase too. Embedded in it is a way of seeing audiences-as "gullible, fickle, herd-like, low in taste and habit" (Williams, 1958, p. 322). Williams went so far as to place manipulation at the center-the unacknowledged center-of the mass communication concept. Degraded, even dangerous, the mass audience needs corrective persuasion, as marked by the rise (and social sanctioning) of the influence industries. Persuasion-for-hire, he wrote,

would clearly not be possible unless it appeared to be ratified by a conception of society which relegates the majority of its members to mob-status. The idea of the masses is an expression of this conception, and the idea of mass-communication a comment on its function. This is the real danger to democracy ... (p. 323)

We have lived with mass-a synonym for mob-rule-for seven decades now. "Mass communication" was first used, fittingly, by the Rockefeller Foundation's John Marshall. "In the last couple of years," he wrote in a 1939 letter, "it has been increasingly clear to me that most of my work has been in a field which for lack of a better name I have come to call mass communications" (quoted in Peters \& Simonson, 2004, p. 11). The term was crystallized in the Communications Seminar that Marshall organized the same year, just as war broke out in Europe. "[I]n the exacting times which lie ahead," the group (Bryson et al., 1940) wrote in a memo, government must "secure consent." Research in the "field of mass communications," Paul Lazarsfeld, Harold Lasswell, and the seminar's other members wrote, "is a new and sure weapon to achieve that end." In a faithful echo of the "mass" concept, the group stated that the world crisis "bewilders the mind" and "threatens sober judgment." Persuasion predicated on popular irrationality was there from the beginning.

Like Silvio Waisbord (Waisbord, Invited Forum), I nominate "media" as a substitute label, one that can be paired with "studies" or gerunded to "communication." Even on its own, media is capacious enough to take in the range of human communication, including face-to-face talk. Co-present speech and gesture, after all, are mediums too. The word has a rich etymology; we are well-positioned to restore one of its longstanding meanings, that of in-betweenness. The dominant, plural form of "media" — as commercial organs of mass communication-only gained its grip in the 1950s, at the height of the broadcast era (Shechtman, 2021). We can keep that meaning in 
the disciplinary cabinet, for sure, while also making room for the broader, in media res sense. The old lament about the field's divide between interpersonal and mass communication has already, in practice, been answered. Our language should catch up.

There is, happily, a nomenclatural shift already underway. Each of the U.S. discipline's four cultures-speech-derived, journalismderived, born-communication, and film-has welcomed "media" onto departmental door-plates (Pooley, 2016, p. 1). The change has registered in the names of journals ("Critical Studies in Media Communication") and scholarly societies (Society for Cinema and Media Studies). Even the Journal of Communication, almost two decades ago, published its "ferment in the field" sequel as Defining Media Studies (Levy \& Gurevitch, 1994).

It's past time to drop "mass" from our name. We have a good alternative. More to the point, the move would count as an implicit repudiation of an implicit slur. 


\section{References}

Blumer, H. (1939). Collective Behavior. In R. E. Park (Ed.), Principles of Sociology, pp. 219-288. New York: Barnes \& Noble.

Borch, C. (2012). The politics of crowds: An alternative history of sociology. Cambridge: Cambridge University Press.

Bryson, L., Free, L. A., Gorer, G., Lasswell, H. D., Lazarsfeld, P. F., Lynd, R. S. ... Waples, D. (1940, July). Research in mass communications. Rockefeller Foundation Archives (RG 1.1., series 200, box 224, folder 2677). Rockefeller Archive Center.

Frezza, D. (2007). The leader and the crowd: Democracy in American public discourse, 1880-1941. Athens: University of Georgia Press.

Le Bon, G. (1896). The Crowd: A Study of the Popular Mind. New York: Macmillan.

Levy, M. R., \& Gurevitch, M. (Eds.). (1994). Defining media studies: Reflections on the future of the field. New York: Oxford University Press

Nye, R. A. (1975). The origins of crowd psychology: Gustave Le Bon and the crisis of mass democracy in the Third Republic. Beverly Hills, CA: SAGE.

Peters, J. D. (2015). The marvelous clouds. Chicago: University of Chicago Press.

Peters, J. D., \& Simonson, P. (2004). Introduction. In J. D. Peters \& P. Simonson (Eds.), Mass communication and American social thought: Key texts, 1919-1968, pp. 1-11. Lanham, MD: Rowman \& Littlefield.

Pooley, J. D. (2016). The four cultures: Media studies at the crossroads. Social Media+ Society, 2(1), 1-4.

Shechtman, A. (2021). Command of media's metaphors. Critical Inquiry, 47(4), 644-674.

Williams, R. (1958). Culture and society, 1780-1950. London: Chatto and Windus. 